\title{
PENERAPAN RECIPROCAL TEACHING UNTUK MENINGKATKAN BERPIKIR KRITIS DAN KEMANDIRIAN BELAJAR SISWA MA
}

\author{
Dayat Hidayat \\ Mahasiswa Program Pascasarjan IKIP Siliwangi Cimahi \\ email: Kangdhidayat@gmail.com
}

\begin{abstract}
Abstrak
The purpose of this study is to know: 1) How the application of reciprocal teaching approach can increase the ability of critical thinking and self regulated learning; 2) whether there is a relationship between the ability to think critically self regulated learning with reciprocal teaching approach. This research is implemented Madrasah Aliyah Negeri Bandung Barat with the population are all MA students in West Bandung regency. The method used in this research is Quasi Eksperimen where there are two classes that one class by using reciprocal teaching and one class again using ordinary learning. The study design was a non-randomized control-treatment group, pretest-posttes design. The population of this study were all students in West Bandung regency and the sample subjects were two classes in MAN Bandung Barat with total number of 72 students, 1 class as experiment class and one class class as control class. The results of research to improve learning ability by using reciprocal teaching and cognitive learning ability with student learning independence with reciprocal teaching approach.
\end{abstract}

Keywords: reciprocal teaching approach, critical thinking, self regulated learning.

\section{Abstrak}

Tujuan penelitian ini adalah untuk mengetahui: 1) Bagaimana penerapan pendekatan reciprocal teaching dapat meningkatakan kemampuan berpikir kritis dan kemandirian belajar siswa; 2) apakah ada kaitan antara kemampuan berpikir kritis dan kemandirian siswa dengan pendekatan reciprocal teaching penelitian ini dilaksanakan Madrasah Aliyah Negeri Bandung Barat dengan populasinya adalah seluruh siswa MA di Kabupaten Bandung Barat. Metode yang dignakan dalam penelitian adalah Quasi Eksperimen dimana ada dua kelas pararel yang satu kelas menggunakan pembelajaran dengan pendekatan reciprocal teaching dan satu kelas lagi menggunakan pembelajaran biasa. Desain penelitian yang digunakan adalah Non-randomize control-treatment group, pretes-posttes design. Populasi penelitian ini adalah seluruh siswa MA se Kabupaten Bandung Barat dan subjek sampelnya adalah dua kelas pada MAN Bandung Barat dengan jumlah jumlah 72 siswa, 1 kelas sebagai kelas eksperimen dan satu kelas kelas sebagai kelas kontrol. Hasil penelitian menunjakan adanya peningkatan kemampuan belajar dengan pendekatan reciprocal teaching dan terdapat kaitan antara kemampuan berpikir kritis dengan kemandirian belajar siswa dengan pendekatan reciprocal teaching.

Kata Kunci: pendekatan reciprocal teaching, berpikir kritis, kemandirian belajar.

\section{PENDAHULUAN}

Dalam menghadapi dunia yang penuh persaingan dan tantangan saat ini diperlukan sumber daya manusia yang memiliki kemampuan tinggi dalam memecahkan berbagai persoalan yang dihadapi. Seseorang yang memiliki kemampuan tinggi harus dapat berpikir logis, rasional, kritis dan kreatif. Kemampuan berpikir logis, rasional, kritis dan kreatif termasuk dalam kemampuan berfikir 
Penerapan Reciprocal Teaching Untuk Meningkatkan Berpikir Kritis Dan Kemandirian Belajar Siswa MA

Dayat Hidayat

tingkat tinggi yang tidak dapat terjadi dengan sendirinya, melainkan diperoleh melalui proses pendidikan, khususnya pendidikan matematika di sekolah.

Salah satu kemampuan berpikir tingkat tinggi tinggi tersebut, khususnya dalam bidang matematika, yaitu berpikir kritis matematis. Berpikir kritis merupakan suatu proses yang bertujuan agar kita dapat membuat keputusankeputusan yang masuk akal, sehingga apa yang kita anggap terbaik tentang suatu kebenaran dapat kita lakukan dengan benar. Berpikir kritis matematis merupakan kemampuan berpikir yang dimiliki siswa yang sangat penting untuk dikembangkan di sekolah, guru diharapkan mampu merealisasikan pembelajaran yang dapat mengaktifkan dan mengembangkan kemampuan berpikir kritis matematis pada siswa, karena setiap siswa memiliki potensi berpikir kritis, tetapi masalahnya bagaimana cara mengembangkan potensi tersebut melalui proses pembelajaran di kelas.

Berpikir kritis merupakan suatu proses menggunakan kemampuan berpikir secara rasional dan reflektif tentang idea atau gagasan yang berhubungan dengan konsep atau masalah yang difokuskan untuk mengambil keputusan tentang apa yang diyakini untuk dilakukan untuk mencapai suatu tujuan.(Ashari, Novianto, \& Indonesia, 2016; Budiman, 2017; Istianah, 2013; Jumaisyaroh \& Hasratuddin, 2015; Jumaisyaroh, Napitupulu, \& Hasratuddin, 2015; Mahmuzah, 2015; Sumarmo, Hidayat, Zukarnaen, Hamidah, \& Sariningsih, 2012)

Sedangkan Susanto (2015). menyatakan bahwa upaya untuk pembentukan kemampuan berpikir kritis siswa yang optimal mensyaratkan adanya kelas yang interaktif, siswa dipandang sebagai pemikir bukan seorang yang diajar, dan pengajar berperan sebagai mediator, fasilitator, dan motivator yang membantu siswa dalam belajar bukan mengajar.

Menurut Glazer (Budiman, 2017), untuk membangun berpikir kritis siwa dalam matematika diperlukan: a) Situasi yang tidak rutin, sehingga individu tidak dapat dengan cepat memahami konsep matematika atau mengetahui bagaimana menentukan persoalan; b) Penggunaan pengetahuan awal, penalaran, dan strategi kognitif; c) Generalisasi, pembuktian, dan evaluasi berpikir reflektif yang melibatkan pengkomunikasian solusi dengan penuh pertimbangan, membuat makna tentang jawaban atau argumen yang masuk akal, menentukan alternatif untuk menjelaskan atau memecahkan persoalan atau membangkitkan perluasan studi selanjutnya

Berdasarkan definisi-definisi yang dikemuka- kan para ahli di atas, terdapat satu kesamaan mengenai pengertian berpikir kritis, yaitu aktivitas mental yang dilakukan menggunakan langkah-langkah dalam metode ilmiah, yaitu: memahami dan merumuskan masalah, mengumpulkan dan menganalisis informasi yang diperlukan dan dapat dipercaya, merumuskan praduga dan hipotesis, menguji hipotesis secara logis, mengambil kesimpulan secara hati-hati, melakukan evaluasi dan memutuskan sesuatu yang akan diyakini atau sesuatu yang akan dilakukan, serta meramalkan konsekuensi yang mungkin terjadi.

Kemandirian belajar kemampuan apektif yang harus dimiliki siswa dalam proses pembelajar di sekolah. Karena dengan memiliki kemandirian belajar siswa dapat belajar dengan atau tanpa bantuan orang lain, dalam merancang atau merencakan pembelajaran, melaksanakan dan menilai sendiri hasil pembelajarannya. (Hidayat \& Sumarmo, 2013; Sumarmo, 2004; Sundayana \& Rostina, 2016).

Terdapat tiga karakteristik utama yang termuat dalam pengertian kemandirian belajar di atas, yaitu (1) Individu merancang belajarnya 
Halaman $1-8$

sendiri sesuai dengan keperluan atau tujuan belajar individu yang bersangkutan; (2) Individu memilih strategi dan melaksanakan rancangan belajarnya; (3) Individu memantau kemajuan belajarnya sendiri, mengevaluasi hasil belajarnya dan dibandingkan dengan standard tertentu.

Menurut Woolfolk (Nurjanah, 2009) menyatakan bahwa faktor-faktor yang mempengaruhi kemandirian belajar meliputi: pengetahuan (knowledge), motivasi (motivation) dan disiplin pribadi (selfdiscipline).

Perlunya pengembangan kemandirian belajar pada individu yang belajar matematika juga didukung oleh beberapa hasil studi temuan antara lain adalah individu yang memiliki kemandirian belajar yang tinggi cenderung belajar lebih baik, mampu memantau, mengevaluasi, dan mengatur belajarnya secara efektif; menghemat waktu dalam menyelesaikan tugasnya, mengatur belajar dan waktu secara efisien, dan memperoleh skor yang lebih tinggi dalam pelajaran sains, Hargis (Sumarmo, 2004). Namun, saat ini kenyataannya bahwa kemandirian belajar belum tersosialisasi dan berkembang di kalangan peserta didik, mereka menganggap bahwa guru satu-satunya sumber ilmu sehingga menyebabkan siswa memiliki ketergantungan dengan orang lain terutama kepada guru.

Dalam pembelajaran di kelas guru dapat mempergunakan pembelajaran berbagai pendekatan pembelajaran salah satunya adalah dengan pendekatan reciprocal teaching. pembelajaran terbalik (reciprocal teaching) adalah strategi belajar melalui kegiatan mengajarkan teman. Pada strategi ini siswa berperan sebagai guru menggantikan peran guru untuk mengajarkan teman-temannya. Pembelajaran terbalik (reciprocal teaching) dikembangkan oleh Anne Marie Palinscar dari
Universitas Michigan dan Ane Crown dari Universitas Illinois USA.

Pembelajaran terbalik (reciprocal teaching) merupakan model pembelajaran yang memberikan kesempatan kepada siswa untuk belajar mandiri, kreatif, dan lebih aktif. Dimana siswa diberi kesempatan untuk mempelajari materi terlebih dahulu, kemudian siswa menjelaskan kembali materi yang dipelajari kepada siswa yang lain. Guru hanya bertugas sebagai fasilitator dan pembimbing dalam pembelajaran, yaitu meluruskan atau memberi penjelasan mengenai materi yang tidak dapat dipecahkan secara mandiri oleh siswa.

Reciprocal Teaching adalah model pembelajaran berupa kegiatan mengajarkan materi kepada teman. Pada model pembelajaran ini siswa berperan sebagai guru untuk menyampaikan materi kepada teman-temannya. Sementara itu guru lebih berperan sebagai model yang menjadi fasilitator dan pembimbing yang melakukan scaffolding. Scaffolding adalah bimbingan yang diberikan oleh orang yang lebih tahu kepada orang yang kurang tahu atau belum tahu.

Trianto (Noriasih, 2011) menyatakan bahwa Reciprocal Teaching terutama dikembangkan untuk membantu guru menggunakan dialog-dialog belajar yang bersifat kerja sama untuk mengajarkan pemahaman bacaan mandiri di kelas. Melalui Reciprocal Teaching siswa diajarkan empat strategi pemahaman pengaturan diri spesifik, yaitu perangkuman, pengajuan pertanyaan, pengklarifikasian, dan prediksi. Reciprocal Teaching merupakan kegiatan yang secara rutin digunakan pembaca. Melalui model reciprocal teaching siswa diharapkan dapat meningkatkan pemahaman atau memantau pemahamannya sendiri. Siswa juga diharapkan belajar melalui mengalami bukan menghafal, sehingga hasil yang diperoleh tidak mudah dilupakan. 
Penerapan Reciprocal Teaching Untuk Meningkatkan Berpikir Kritis Dan Kemandirian Belajar Siswa MA

Dayat Hidayat

Hasil penelitian Herman dan Irwan

(2014:13) menemukan bahwa terdapat

2. Siswa mendiskusikan materi tersebut bersama dengan teman satu kelompoknya.

perbedaan secara berarti antara hasil belajar siswa yang diajar dengan menggunakan model

Reciprocal Teaching dengan yang diajarkan dengan model konvensional. Perbedaan tersebut terletak pada aspek rata-rata hasil belajar matematika tingkat pemahaman dan kegiatan belajar mengajar

Menurut Palinscar (Noriasih, 2011) model pembelajaran Reciprocal Teaching terdapat empat strategi yang digunakan, yaitu (Hayati, 2012:17):

1. Question Generating (Membuat Pertanyaan). Dalam strategi ini, siswa diberi kesempatan untuk membuat pertanyaan terkait materi yang sedang dibahas.

2. Clarifying (Menjelaskan). Strategi Clarifying ini merupakan kegiatan penting saat pembelajaran, terutama bagi siswa yang mempunyai kesulitan dalam memahami suatu materi. Siswa dapat bertanya kepada guru tentang konsep yang dirasa masih sulit atau belum bisa dipecahkan bersama kelompoknya.

3. Predicting (Memprediksi). Strategi ini merupakan strategi dimana siswa melakukan hipotesis atau perkiraan mengenai konsep apa yang akan didiskusikan selanjutnya oleh penyaji.

4. Summarizing (Merangkum). Dalam strategi ini terdapat kesempatan bagi siswa untuk mengidentifikasikan dan mengintegrasikan informasi-informasi yang terkandung dalam materi.

Sedangkan menurut Suyitno (2006:34), langkah-langkah dalam pembelajaran Reciprocal Teaching adalah sebagai berikut:

1. Guru menyiapkan materi yang akan dikenai model Reciprocal Teaching. Materi tersebut diinformasikan kepada siswa.

3. Siswa diminta untuk membuat pertanyaan terkait materi yang sedang dipelajari.

4. Guru menunjuk salah satu siswa sebagai wakil dari kelompoknya untuk menjelaskan hasil temuannya di depan kelas.

5. Siswa diberi kesempatan untuk mengklarifikasi materi yang sedang dibahas yaitu dengan bertanya tentang materi yang masih dianggap sulit sehingga tidak dapat dipecahkan dalam kelompok. Guru juga berkesempatan untuk melakukan kegiatan tanya jawab untuk mengetahui sejauh mana pemahaman konsep siswa.

6. Siswa mendapat tugas soal latihan secara individual termasuk soal yang mengacu pada kemampuan siswa dalam memprediksi pengembangan materi tersebut.

7. Siswa diminta untuk menyimpulkan materi yang sedang dibahas.

\section{METODE PENELITIAN}

Jenis penelitian yang digunakan dalam penelitian ini adalah kuasi eksperimen yang bertujuan untuk mengetahui peningkatan kemampuan berpikir kritis matematis dan kemandirian belajar siswa melalui pembelajaran dengan pendekatan reciprocal teaching.

Penelitian ini dilaksanakan di MAN Bandung Barat yang berlokasi di Jalan Raya Cililin Utara No. 3 Cililin Kabupaten Bandung Barat, pada semester genap tahun pelajaran 2017/2018 yang berlangsung pada awal sampai akhir Maret 2018 selama 5 kali pertemuan untuk kelas eksperimen dan kelas kontrol.

Populasi penelitian ini adalah seluruh siswa di MAN Bandung Barat sedangkan sampel penelitian ini adalah siswa kelas $\mathrm{X}$ IPA MAN Bandung Barat dengan 
Halaman $1-8$

mengambil sampel dua kelas sebanyak 70 orang, terdiri dari 35 orang siswa pada kelas X IPA-3 sebagai kelas eksperimen dan 35 orang siswa pada kelas X IPA-2 sebagai kelas kontrol.

Variabel bebas dalam penelitian ini adalah pembelajaran dengan pendekatan recirocal teaching, sedangkan variable terikatnya adalah kemampuan berpikir kritis matematis dan kemandirian belajar siswa.

Desain penelitian yang digunakan dalam penelitian ini adalah desain kelompok pretest-posttest control group design. Instrumen yang digunakan untuk memperoleh data dalam penelitian ini adalah tes kemampuan berpikir kritis matematis dan skala kemandirian belajar yang mana nantinya akan dinilai oleh validator yang berkompeten yang meliputi dosen dan guru matematika di sekolah dan diuji cobakan terhadap responder di luar kelas sampel. Data dalam penelitian ini terdiri dari pengujian normalitas, homogenitas, pengujian perbedaan rata-rata, perhitungan indeks gain dan pengujian hipotesis.

Pengujian seluruh hipotesis statistik dalam penelitian ini digunakan SPSS Statistic 22.

\section{HASIL DAN PEMBAHASAN}

Metode penelitian yang digunakan adalah quasi-eksperimen untuk melihat pengaruh pendekatan reciprocal teaching, Pada kelas eksperimen proses pembelajaran dilakukan menggunakan pendekatan reciprocal teaching, sedangkan pada kelas kontrol, proses pembelajaran dilakukan dengan menggunakan model pengajaran konvensional. Selanjutnya kedua kelas dievaluasi untuk melihat perubahan /peningkatan yang terjadi terhadap kemampuan berfikir kritis setelah mendapat perlakuan pendekatan reciprocal teaching dengan yang tidak mendapat perlakuan. Instrumen yang digunakan pada penelitian ini berupa tes untuk memperoleh data tentang hasil belajar siswa. Soal tes yang digunakan terlebih dilakukan validasi isi dan validasi empiris. Selanjutnya melalui analisis hasil tes dilakukan uji hipotesis untuk menarik kesimpulan.

Penelitian ini dilaksanakan dengan menggunakan dua kelas yang dijadikan sebagai sampel penelitian yaitu kelas X MIA.3 sebagai kelas eksperimen dan kelas X MIA.2 sebagai kelas kontrol. Pada kelas eksperimen diberikan perlakuan dengan pembelajaran pendekatan reciprocal teaching yang terdiri dari 7 langkah, yaitu: 1) Guru menyiapkan materi yang akan dikenai model Reciprocal Teaching; 2) Siswa mendiskusikan materi tersebut bersama dengan teman satu kelompoknya; 3) Siswa diminta untuk membuat pertanyaan terkait materi yang sedang dipelajari; 4) Guru menunjuk salah satu siswa sebagai wakil dari kelompoknya untuk menjelaskan hasil temuannya di depan kelas; 5) Siswa diberi kesempatan untuk mengklarifikasi materi yang sedang dibahas yaitu dengan bertanya tentang materi yang masih dianggap sulit sehingga tidak dapat dipecahkan dalam kelompok; 6) Siswa mendapat tugas soal latihan secara individual termasuk soal yang mengacu pada kemampuan siswa dalam memprediksi pengembangan materi tersebut; 7) Siswa diminta untuk menyimpulkan materi yang sedang dibahas.

Sedangkan pada kelas kontrol tidak diberikan perlakuan sehingga pembelajaran tetap dilaksanakan seperti biasa dengan menggunakan metode konvensional yaitu metode ceramah plus dengan lembar diskusi. Untuk mengetahui perbedaan peningkatan hasil belajar dengan menggunakan pendekatan reciprocal teaching. Siswa pada kelas eksperimen dan siswa kelas kontrol diberi soal 
pretes untuk menguji kemampuan awal siswa serta soal postes untuk menguji kemampuan akhir setelah diberi perlakuan.

Berdasarkan data pada kondisi awal, kedua sampel memiliki data yang homogen jika dianalisis dari nilai mid semester. Kemudian untuk nilai rata-rata kemampuan awal kelas eksperimen diketahui dari nilai pretes sebesar 41,92 sedangkan kelas kontrol 36,22. Dengan uji homogenitas dua varians, didapatkan bahwa $\mathrm{F}_{\text {hitung }}<\mathrm{F}_{\text {tabel, }}$, yang berarti bahwa kedua kelompok memiliki varians data yang sama dan berangkat pada kondisi yang sama pula. Setelah dilakukan pembelajaran dengan pendekatan reciprocal teaching pada kelompok eksperimen, rata-rata hasil posttes yang diperoleh mencapai 77,08. Pada kelas kontrol yang diajar dengan menggunakan metode konvensional, rata-rata hasil postes hanya mencapai 72,81. Berdasarkan uji perbedaan dua rata-rata sampel independen menunjukkan bahwa $t$ hitung $(2,139)>t$ table $(1,67)$ pada taraf signifikan $95 \%$ yang berarti terdapat perbedaan hasil belajar yang signifikan antara kelas eksperimen dan kelas kontrol. Hasil uji perbedaan ini juga diperkuat oleh rata-rata hasil $\mathrm{N}$-gain kelas eksperimen 0,60 dan rata-rata $\mathrm{N}$ gain kelas kontrol 0,57 yang menunjukkan bahwa peningkatan hasil belajar kelas eksperimen lebih baik daripada kelas kontrol. Pada kelas eksperimen yang diajar dengan menggunakan pendekatan reciprocal teaching terbukti memberikan kontribusi terhadap peningkatan berpikir kritis dan kemandirian belajar siswa berdasarkan uji-t.

Selain untuk mengtatahui peningkatan kemampuan berpikir kritis siswa dengan pendekatan reciprocal teaching, pada penelitian ini juga ingin mengetahui pengaruh kemandirian belajar terhadap kemampuan berpikir kritis siswa. Dari hasil perhitungan melalui SPSS diperoleh hasil sebagai berikut: kedua dua berdistribusi normal, kemudian dilanjutkan dengan uji regresi linear dan diperoleh hasil: Berdasarkan nilai t: diperoleh $\mathrm{t}$ hitung $(14,383)>t$ table $(0,683)$, maka terdapat hubungan yang signifikan antara kemandirian belajar dengan kemampuan berpikir kritis.

Jika dilihat besarnya pengaruh penerapan pendekatan reciprocal teaching terhadap kemampuan berpikir kritis dan kemandirian belajar siswa pada kelas eksperimen, persentasenya hanya mencapai $34,81 \%$. Hal ini menunjukkan bahwa tingginya kemampuan berpikir kritis dan kemandirian belajar siswa kelas eksperimen tidak sepenuhnya dipengaruhi oleh penerapan pendekatan reciprocal teaching melainkan ada faktor lain yang mempengaruhinya, yakni faktor internal salah satunya faktor psikologis. Sekurang-kurangnya ada tujuh faktor yang tergolong ke dalam factor psikologis yang mempengaruhi belajar. Faktorfaktor itu adalah: intelegensi, perhatian, minat, bakat, motif, kematangan, dan kelelahan.

Perbedaan kemampuan berpikir kritis dan kemandirian belajar siswa antara siswa yang belajar matematika menggunakan pendekatan reciprocal teaching dan siswa yang belajar matematika melalui metode konvensional dipengaruhi juga oleh berbagai faktor, diantaranya adalah metode mengajar yang digunakan. Metode konvensional yang diterapkan pada kelas kontrol adalah metode ceramah dengan lembar diskusi siswa. Pada awal pembelajaran, guru memberikan rangkuman materi pelajaran agar mempermudah siswa dalam proses pembelajaran. Selanjutnya guru memberikan apersepsi untuk mengetahui sejauh mana pengetahuan siswa tentang materi yang akan diajarkan.

Guru menerangkan dan menyampaikan materi dengan metode ceramah. Selanjutnya guru memberikan lembar diskusi dan guru 
Halaman $1-8$

membimbing siswa dalam mengerjakan latihan tersebut. Diakhir pembelajaran dilakukan evaluasi terhadap proses pembelajaran yang telah berlangsung dan kemudian guru memberikan tugas dan persiapan untuk pertemuan berikutnya. Pembelajaran dengan metode konvensional bisa saja menghasilkan nilai yang tinggi akan tetapi hal tersebut tidak diikuti dengan adanya eksplorasi kemampuan berpikir siswa dalam memecahkan masalah dan memahami konsep berdasarkan pengalaman. Pada pembelajaran kelompok eksperimen, fungsi guru hanya sebagai fasilitator, yaitu memberikan bimbingan / pengarahan seperlunya kepada siswa.

Keaktifan siswa lebih ditekankan pada proses pembelajaran. Dengan adanya keaktifan dalam diskusi untuk memecahkan masalah tersebut akan menumbuhkan motivasi belajar yang tinggi pada siswa dan pada akhirnya akan berpengaruh terhadap kemampuan kritis siswa. Tingkat keaktifan siswa pada kelompok eksperimen lebih tinggi dari pada pembelajaran kelompok kontrol. Aktivitas yang dilakukan siswa pada pembelajaran denagn pendekatan reciprocal teaching diseluruh proses pembelajaran mulai dari menemukan masalah, melakukan percobaan yang sesuai untuk mencari pemecahan masalah yang dihadapi baik berdiskusi maupun mencari informasi melalui studi pustaka, hingga menyimpulkan seluruh kegiatan pembelajaran yang telah dilakukan oleh siswa.

Dalam pembelajaran ini, guru menciptakan strategi yang tepat agar siswa memiliki motivasi belajar yang tinggi, mampu menerapkan teori yang telah didapat dalam kehidupan nyata. Pembelajaran matematika dengan pendekatan reciprocal teaching ini dapat mengembangkan kemampuan berpikir kritis siswa. Kemampuan berpikir kritis siswa dicerminkan dalam lima dari enam indikator kemampuan yaitu Reason (alasan), Inference (menyimpulkan), Situasion (situasi), Clarity (kejelasan), dan Overview (pandangan menyeluruh).

Hasil tes yang dicapai Reason (alasan) 47,53\%, Inference (menyimpulkan) 44,4\%, Situasion (situasi) 55,56\%, Clarity (kejelasan) $48,76 \%$ dan Overview (pandangan menyeluruh). $40,74 \%$.

Hasil akhir tes setelah melakukan pembelajaran bahwa untuk kelas kontrol 48\% berada pada tahap transisi dan $52 \%$ berada pada tahap operasional formal. Rata-rata kelas kemampuan siswa berada pada tahap transisi. Data hasil kelas eksperimen diperoleh adalah $25 \%$ siswa yang berada pada tahap transisi dan $75 \%$ sudah berada pada tahap berpikir formal. Rata-rata kelas kemampuan siswa sudah berada pada tahap berpikir formal. Dari analisis data dapat disimpulkan bahwa pembelajaran pendekatan reciprocal teaching terdapat pengaruh terhadap kemampuan berpikir kritis siswa.

\section{SIMPULAN DAN SARAN}

Berdasarkan hasil analisis data penelitian dan pembahasan, dapat ditarik kesimpulan bahwa terdapat pengaruh pendekatan reciprocal teaching terhadap kemampuan berpikir kritis pada siswa MAN Bandung Barat. Dimana kemampuan berpikir kritis siswa dengan menggunakan pendekatan reciprocal teaching lebih baik dibandingkan dengan kemampuan berpikir kritis siswa yang menggunakan metode konvensional. Besar pengaruh pendekatan reciprocal teaching terhadap kemampuan berpikir kritis adalah 34,81\%.

Dalam pembelajaran dengan pendekatan reciprocal teaching guru hendaknya dapat meningkatkan kreativitasnya agar siswa dapat melaksanakan pembelajaran dengan baik. Hal tersebut juga sebaiknya didukung oleh sistem 
Penerapan Reciprocal Teaching Untuk Meningkatkan Berpikir Kritis Dan Kemandirian Belajar Siswa MA

Dayat Hidayat

pendidikan yang baik. Dalam proses pembelajaran dengan pendekatan reciprocal teaching sebaiknya dapat menggunakan media pembelajaran lain yang dapat membantu seperti power point untuk memperjelas langkahlangkah pembelajaran.

\section{REFERENSI}

Ashari, A., Novianto, E., \& Indonesia, P. B. C. (2016). Pembelajaran Sumbang Saran Berpikir Kritis Siswa Smp. Jurnal Pendidikan, 1(11), 2101-2105.

Budiman, H. (2017). Peningkatan kemampuan berpikir kritis dan kreatif matematis siswa melalui pendekatan pembelajaran berbasis masalah berbantuan. https://www.researchgate.net/publication/ 317077179.

Hidayat, W., \& Sumarmo, U. (2013). Kemampuan Komunikasi dan Berpikir Logis Matematik serta Kemandirian Belajar: Eksperimen terhadap Siswa SMA Menggunakan Pembelajaran Berbasis dan Strategi Think-Talk-Write. Delta-Pi: Jurnal Matematika Dan Pendidikan Matematika, 2(1), 1-14.

Istianah, E. (2013). Meningkatkan Kemampuan Berpikir Kritis dan Kreatif Matematik dengan Pendekatan Model Eliciting Activities (MEAs) Pada Siswa SMA. Infinity, 2(1), 43-54.

Jumaisyaroh, T., \& Hasratuddin, E. E. N. (2015). Peningkatan Kemampuan Berpikir Kritis Matematis dan Kemandirian Belajar Siswa SMP Melalui Pembelajaran Berbasis Masalah. ISSN: 2088-687X, 5(1).

Jumaisyaroh, T., Napitupulu, E. E., \& Hasratuddin, H. (2015). Peningkatan Kemampuan Berpikir Kritis Matematis Dan Kemandirian Belajar Siswa Smp Melalui Pembelajaran Berbasis Masalah. Kreano, Jurnal Matematika Kreatif-

$\begin{array}{lrr}\text { Inovatif, } & 5(2), & 157 .\end{array}$

https://doi.org/10.15294/kreano.v5i2.3325

Mahmuzah, R. (2015). Peningkatan Kemampuan Berpikir Kritis Matematis Siswa Smp Melalui Pendekatan Problem Posing. Jurnal Peluang, 4(1), 2302-5158.

Noriasih, N. K. (2011). Pengaruh Model Pembelajaran Reciprocal Teaching.

Nurjanah, E. (2009). Efektivitas Metode Problem Posing Terhadap Self- Regulated Learning Dan Pemahan Konsep Matematika SMK, 83-91.

Sumarmo, U. (2004). Kemandirian belajar: Apa, mengapa, dan bagaimana dikembangkan Pada peserta didik. Makalah Disajikan Pada Seminar Pendidikan Matematika Di Jurusan Pendidikan Matematika FMIPA Universitas Negeri Yogyakarta, 8(1983), 9. https://doi.org/10.1111/j.10958312.2011.01677.x

Sumarmo, U., Hidayat, W., Zukarnaen, R., Hamidah, M., \& Sariningsih, R. (2012). Kemampuan dan Disposisi Berpikir Logis, dan Kreatif Matematika (Eksperimen terhadap Siswa SMA Menggunakan Pembelajaran Berbasis Masalah dan Strategi Think-Talk-Write). Jurnal Pengajaran Matematika Dan Ilmu Pengetahuan Alam, 17(1), 17. https://doi.org/10.18269/jpmipa.v17i1.228

Sundayana, \& Rostina. (2016). Kaitan antara Gaya Belajar, Kemandirian Belajar, dan Kemampuan Pemecahan Masalah Siswa SMP dalam Pelajaran Matematika. Jurnal Pendidikan Matematika STKIP Garut, Volume 8, 31-40.

Susanto, A. 2015. Teori Belajar dan Pembelajaran di Sekolah Dasar. Jakarta: Prenadamedia Group 